\title{
Changes in quality characteristic of immature flat persimmon (Diospyros kaki Thunb) during heat treatment aging
}

\author{
Hye-Jin Sim ${ }^{1}$, Jae-Ran Kang ${ }^{1}$, Min-Jung Kang ${ }^{1}$, Myoung-Hyo Choi ${ }^{1}$, Hwa-Jin Suh ${ }^{2}$, \\ Jung-Hye Shin ${ }^{1 *}$ \\ ${ }^{1}$ Namhae Garlic Research Institute, Namhae 52430, Korea \\ ${ }^{2}$ Gyeongbuk Natural Color Industry Institute, Yeongcheon 38896, Korea
}

\section{열처리 숙성 중 반시 미숙과의 이화학적 특성}

\author{
심혜진 ${ }^{1} \cdot$ 강재란 $^{1} \cdot$ 강민정 $^{1} \cdot$ 최명효 ${ }^{1} \cdot$ 서화진 $^{2} \cdot$ 신정혜 $^{1 *}$ \\ ${ }^{1}($ 재 $)$ 남해마늘연구소, ${ }^{2}($ 재 $)$ 경북천연염색산업연구원
}

\begin{abstract}
The objective of this study was to investigate physicochemical and antioxidant characteristics of immature flat persimmon during 7 heat treatment aging steps. The $\mathrm{pH}$ decreased, and hence, acidity increased with aging. Hunter $L$ value decreased with aging. The a value rapidly increased until step 3 , whereas the $b$ value decreased. Fructose content decreased while glucose contents slightly increased during aging. Hardness, chewiness and gumminess rapidly decreased, indicating softening in texture, but it was negligible after aging step 3. Phenolic compounds including gallic acid and homogentisic acid were detected at step 3 and then gradually increased with aging. However, contents of flavonoid and tannin were much higher in step 1 sample than others. The antioxidant activities observed by DPPH, ABTS, and FRAP assay were the highest at step 1 possibly due to the higher levels of flavonoids and tannin acid in the step 1 sample.
\end{abstract}

Key words : immature flat persimmon, quality characteristic, aging, antioxidant activity

\section{서 론}

열처리 공정을 거친 식품의 항산화 활성은 페놀화합물의 분해 및 공정 중 갈색 물질의 생성 정도에 영향을 받는다(1). 갈변화 반응을 통해 생성된 물질은 식품의 색을 갈색으로 변화시키고, 품질에 직접적 또는 간적적인 영향을 주며 이 때 생성된 갈색 물질은 항산화 활성이 높으며, 고온에서 가열될수록 항산화 활성은 더 높아진다 $(2,3)$. 이러한 기작 은 갈색 물질인 melanoidins의 환원성 성분에 의해 라디칼 소거 작용, maillard 반응물에 의한 과산화물 분해작용, maillard 반응에 의한 중합물의 금속봉쇄작용과 시너지 효

*Corresponding author. E-mail : whanbee@hanmail.net Phone : 82-55-860-8947, Fax : 82-55-860-8960

Received 17 November 2015; Revised 7 March 2016; Accepted 7 March 2016.

Copyright (c) The Korean Society of Food Preservation. All rights reserved.
과, 함질소 화합물에 의한 질소 원자의 유리전자대로부터 proton의 이동작용에 따른다고 보고된 바 있다(4).

감(persimmon)은 전 세계에 걸쳐 널리 분포되어 있는 감나무(ebenaceae)과 감나무속(diospyros)에 속하는 식물로 1,000 여종이 있으며, 열대나 아열대 지방에서 주로 재배되 고 있고 보통 온대 지방의 감이 식용으로 많이 이용된 다.(5,6). 감은 우리나라의 기후 풍토에 적합하여 전국 어디 에서나 재배가 가능하므로 우리나라 고유의 과실로 국제적 경쟁력이 높을 것으로 예상되지만 감에 대한 수요가 크지 않아 농가소득을 촉진할 만한 수준에는 이르지 못하고 있다 (7). 다른 과실과는 달리 미숙과일 때는 탄닌 세포에 함유된 수용성 탄닌 성분에 의해 떫은맛을 나타내는데, 과실이 성 숙하면서 점차 탄닌 성분이 불용화되어 생육 중 탈삽되는 것을 단감이라고 하고 그렇지 않은 것을 떫은 감이라고 한다(8). 단감은 대부분 생과로 이용되지만, 떫은 감의 경우 는 수확 후 수일이 지나면 후숙이 진행되어 쉽게 연시가 되기 때문에 장기저장이 곤란하며(9) 탈삽 또는 연화과정을 
거쳐야 할 뿐만 아니라 기호적으로 단감에 비하여 선도가 낮고 그 사용 폭이 좁아 자연탈삽, $\mathrm{CO}_{2} \mathrm{gas}$ 와 에탄올 처리 등의 적절한 탈삽이나 곶감, 감 말랭이 및 감식초 등으로 가공되어 왔다(10). 떫은 감 품종 중 경상북도 청도군에서 주로 재배되고 있는 청도반시는 총 재배면적이 $1,729 \mathrm{ha}$ 이 고 총 생산량은 연간 약 25,000 톤으로 전국에서 유일하게 감에 씨가 없으며, 육질이 연한 것이 특징으로 품질이 비교 적 우수하고 어떤 형태로든 가공이 가능하다 $(11,12)$.

감의 주성분은 당질로서 약 15 16\% 정도이며 주로 포도 당과 과당의 함유량이 높고(13), 비타민 $\mathrm{A}$, 비타민 $\mathrm{C}$, 가용 성 탄닌과 $\mathrm{Ca}, \mathrm{K}, \mathrm{Mg}$ 등 무기염류가 풍부한 알칼리성 식품 이다(14). 감은 항산화성(15), 혈당의 항상성 유지(16), 항동 맥경화 활성(17), 알코올 대사촉진과 항혈액 응고(18) 등의 생리활성이 알려져 있으며, 국내에서는 고추장(13), 설기떡 (14,19), 식빵(18), 두부(20), 청포묵(21), 와인(22), 잼(23) 등 감을 이용한 가공제품에 대한 연구가 많이 이루어져 있다.

감의 재배 과정에서 과실의 배육과 상품성 향상을 위해 미숙과일 때 일부를 제거하게 되는데 이때 발생하는 미숙과 의 일부는 예로부터 추출하여 의류, 그물 및 종이 염색 등 염료로 사용되어 왔고, 일본에서는 미숙감 착즙액을 발효 시켜 기침, 중풍, 뇌졸중, 화상 등 다양한 증상에 대한 민간 의학 소재, 천연염료 및 도료 그리고 술 제조 과정에서 청징 제로 이용해 왔다(5). 그러나 미숙과의 대부분은 적과된 채 버려져 주변 환경을 오염시키는 요인으로 작용하고 있는 실정이다(24). 미숙과의 경우 완숙과에 비해 항산화 효능이 높다고 알려져 있어 이것을 자원으로 활용한다면 농업생산 성에 도움이 되는 자원으로써 가치가 있을 것으로 판단된다(25).

현재까지 떫은 감에 관한 연구로는 떫은 감에서 분리한 탄닌 성분의 기능적 특성(8), 유통특성 분석(9), 탄닌 성분의 패턴변화(26), 탈삽에 따른 품질특성 변화(11) 등의 몇몇 보고가 있었지만 그 수가 많지 않았다. 특히 반시 미숙과에 대한 연구는 더욱 미흡한 실정이므로 미숙과의 가공법 제안 및 기능성 규명을 위한 기초 연구의 일환으로 최근 마늘, 인삼, 마, 대추 등의 가공에 적용되고 있는 열처리 숙성 기술을 이용해 미숙과를 가공함에 있어 품질관련 인자 및 항산화 활성의 변화를 분석하였다.

\section{재료 및 방법}

\section{시료 제조}

반시 미숙과는 9월경에 경북 청도산을 구입하여 직경 $6.0 \mathrm{~cm}$, 높이 $4.0 \mathrm{~cm}$, 무게 $75.5 \mathrm{~g}$ 정도의 것을 시료로 사용하 였고, 반시의 숙성조건은 Table 1과 같이 7 step으로 나누어 실시하였으며, 각 단계별 물리적 - 화학적 변화 및 특성을 분석하였다.
Table 1. Conditions for aging of immature flat persimmon

\begin{tabular}{ccc}
\hline Aging step & Temperature $\left({ }^{\circ} \mathrm{C}\right)$ & Aging time $(\mathrm{hr})$ \\
\hline 1 & 70 & 12 \\
2 & 90 & 24 \\
3 & 70 & 48 \\
4 & 70 & 72 \\
5 & 70 & 96 \\
6 & 70 & 120 \\
7 & 70 & 144 \\
\hline
\end{tabular}

\section{수분 함량 분석}

수분 함량은 숙성단계별 반시를 분쇄기(HMF-3450S, Hanil, Seoul, Korea)로 분쇄한 후 약 $1.0 \mathrm{~g}$ 을 취하여 적외선 수분측정기(MB45, Ohaus, Pine Brook, NJ, USA)로 3번 이 상 반복 측정하였다.

\section{$\mathrm{pH}$ 및 산도 측정}

시료의 $\mathrm{pH}$ 와 적정산도는 자동 적정기(G20 compact titrator, Mettler toledo, Greifensee, Switzerland)를 이용하여 측정하였다. 분쇄한 시료 $5 \mathrm{~g}$ 을 취해 증류수를 가하여 50 $\mathrm{mL}$ 가 되도록 한 후 혼합 진탕한 다음 여과지(No. 2, Advantec, Tokyo, Japan)로 여과한 여액을 일정량 취하여 $\mathrm{pH}$ 를 측정하였고, 적정산도는 $0.1 \mathrm{~N} \mathrm{NaOH}$ 용액으로 시료 액의 $\mathrm{pH}$ 가 8.4가 될 때까지 적정하여 초산 양으로 환산하였 다.

\section{색도 측정}

숙성단계에 따른 반시의 색도 측정은 반시의 꼭지부분을 제거한 뒤 꼭지를 중심으로 수직으로 2 등분 한 후 이를 다시 수평으로 3 등분 한 다음 가운데 부분을 취해 $2.5 \times 2 \times 1$ $\mathrm{cm}$ 의 크기로 절단하여 색도 측정에 사용하였다. 색도는 색차계(Ultrascan VIS, Hunter Lab, VA, USA)를 이용하여 측정하였으며, 이때 표준 백판의 $\mathrm{L}, \mathrm{a}$ 및 b 값은 각각 99.41 , -0.11 및 0.03 이었다. 각 시료는 5 회 이상 반복 측정하여 평균값으로 나타내었다.

\section{조직감 측정}

색도 측정 시와 동일한 방법으로 처리한 시료를 texture analyzer(TA-XT express, Stable Micro Systems, Surrey, England)를 이용하여 각 시료 군별로 10 개 이상 시료의 중심 부 조직감을 측정하였다. 이때 TPA(texture profile analysis) 를 위한 texture analyzer의 조건은 $\Phi 4 \mathrm{~mm}$ core를 사용하였 고, pre-test speed는 $1 \mathrm{~mm} / \mathrm{sec}$, test speed는 $2 \mathrm{~mm} / \mathrm{sec}$, post-test speed는 $5 \mathrm{~mm} / \mathrm{sec}$, test distance는 $3 \mathrm{~mm}$, time은 $5 \mathrm{sec}$, trigger force는 $5 \mathrm{~g}$ 이었다. 


\section{유리당 함량 분석}

분쇄한 시료 $5 \mathrm{~g}$ 에 3 차 증류수 $30 \mathrm{~mL}$ 을 가하여 30 분간 추출한 뒤 $0.45 \mu \mathrm{m}$ syringe filter로 여과하여 HPLC(Agilent 1260, Hewlett-Packard Co., Palo Alto, CA, USA)로 분석하였 다. 분석용 column은 COSMOSIL Sugar-D(4.6×250 mm, Nacalai Tesque Inc., Kyoto, Japan)를 사용하였고, 이동용매 는 water와 acetonitrile을 3:7으로 혼합한 용액을 사용하였 으며, 이동상의 속도는 $1.0 \mathrm{~mL} / \mathrm{min}$, 시료 주입량은 $10 \mu \mathrm{L}$, 검출기는 $\mathrm{ELSD}$ (Agilent LT-ELSD G4128A, Santa Clara, $\mathrm{CA}, \mathrm{USA}$ )를 사용하였으며, 분석 온도는 $30^{\circ} \mathrm{C}$ 를 유지하였 다. 총 3종의 유리당(fructose, glucsoe, sucrose) 표준물질을 시료와 동일한 조건에서 분석하여 머무름 시간을 비교해 확인하였으며, 각각의 검량곡선으로부터 그 함량을 산출하 였다.

\section{항산화 물질 정량}

플라보노이드 함량 분석을 위한 시료액은 분쇄한 시료 $5 \mathrm{~g}$ 에 증류수를 가해 $50 \mathrm{~mL}$ 로 만든 다음 균질화한 후 여과 지(No. 2, Advantec)로 여과한 여액을 사용하였고 Moreno 등(27)의 방법에 따라 측정하였다. 시료액 $1 \mathrm{~mL}$ 에 증류수 $1 \mathrm{~mL}, 10 \%$ aluminum nitrate $0.1 \mathrm{~mL}, 1 \mathrm{M}$ potassium acetate $0.1 \mathrm{~mL}$ 및 $80 \%$ ethanol $4.3 \mathrm{~mL}$ 를 차례로 가한 후 혼합하여 실온의 암실에서 40 분간 정치한 다음 분광광도계를 이용하 여 $415 \mathrm{~nm}$ 에서 흡광도를 측정하였다. Quercetin(Sigma Co., St. Louis, MO, USA)을 표준물질로 하여 얻은 검량선으로 부터 총 플라보노이드 함량을 계산하였다.

총 페놀 화합물 분석을 위한 시료액은 시료 $1 \mathrm{~g}$ 에 $60 \%$ $\mathrm{EtOH}$ 를 $20 \mathrm{~mL}$ 가하여 60 분간 추출하여 여과지(No. 2, Advantec)로 여과 한 후, 원심분리기(Combi-514R, Hanil, Seoul, Korea)를 이용해 $3,000 \mathrm{rpm}$ 에서 10 분간 원심분리하 고, 상층액을 $0.45 \mu \mathrm{m}$ syringe filter로 여과하여 HPLCDAD(Agilent 1260, Hewlett-Packard Co., Palo Alto, CA, USA)로 분석하였다. 분석용 column은 Agilent Zorbax SB-C18(4.6 $\times 250 \mathrm{~mm}, 5 \mu \mathrm{m}$, Agilent Technologies, Palo Alto, $\mathrm{CA}, \mathrm{USA}$ )을 사용하였고, 이동상 용매는 $0.1 \%$ formic acid 수용액과 acetonitrile에 용해한 $0.1 \%$ formic acid를 시간에 따라 혼합비율을 달리하면서 분석하였다. 이동상의 속도는 $0.7 \mathrm{~mL} / \mathrm{min}$, 시료 주입량은 $10 \mu \mathrm{L}, \mathrm{UV}$ 검출기의 파장은 280 와 $340 \mathrm{~nm}$ 로 조절하였다.

총 탄닌 함량은 Duval과 Shetty(28)의 방법에 따라 분쇄한 시료 $5 \mathrm{~g}$ 에 증류수를 가하여 $50 \mathrm{~mL}$ 가 되도록 한 후 진탕 혼합한 다음 여과지(No. 2, Advantec)로 여과한 여액을 사용 하였다. 시료액 $1 \mathrm{~mL}$ 에 $95 \%$ ethanol $1 \mathrm{~mL}$ 와 증류수 $1 \mathrm{~mL}$ 를 차례로 가하여 충분히 혼합한 후 $5 \% \mathrm{Na}_{2} \mathrm{CO}_{3}$ 용액 $1 \mathrm{~mL}$ 와 $1 \mathrm{~N}$ Folin-ciocalteu reagent(Sigma Co.) $0.5 \mathrm{~mL}$ 를 가한 후 실온에서 60 분간 발색시킨 다음 분광광도계를 이용하여 $725 \mathrm{~nm}$ 에서 흡광도를 측정하였으며, tannic acid(Sigma Co.,
St. Louis, MO, USA)를 표준물질로 검량선을 작성하여 시 료 $\mathrm{g}$ 중의 $\mathrm{mg}$ tannic acid equivalent(TAE)로 나타내었다.

\section{항산화 활성 측정}

분쇄한 시료 $5 \mathrm{~g}$ 을 취해 증류수를 가하여 $50 \mathrm{~mL}$ 가 되도록 한 후 30 분간 진탕 추출한 후 여과지(No. 2, Advantec)로 여과한 여액을 항산화 활성 측정용 시료액으로 사용하였 다.

$\mathrm{DPPH}(1,1-\mathrm{Diphenyl-2-picrylhydrazyl)}$ 라디칼 소거활성 은 $\mathrm{DPPH}$ 에 대한 전자공여 활성으로 나타낸 것으로 시료액 과 DPPH 용액 $(5 \mathrm{mg} / 100 \mathrm{~mL}$ methanol)을 동량으로 혼합한 다음 실온에서 20 분간 반응시킨 후 분광광도계를 이용하여 $525 \mathrm{~nm}$ 에서 흡광도를 측정하였다(29).

ABTS(2,2-azinobis-(3-ethylbenzo-thiazoline-6-sulphonate) 라디칼 소거활성은 $7 \mathrm{mM}$ 의 ABTS용액에 potassium persulfate를 $2.4 \mathrm{mM}$ 이 되도록 용해시킨 다음 암실에서 $12 \sim 16$ 시간 동안 반응시킨 후 $415 \mathrm{~nm}$ 에서 흡광도가 1.5 가 되도록 증류수로 조정한 $\mathrm{ABTs}$ 용액을 사용하였다. ABTS 용액에 동량의 시료액을 혼합하고 실온에서 10 분간 반응시 킨 다음 분광광도계를 이용하여 $415 \mathrm{~nm}$ 에서 흡광도를 측정 하였다(30). DPPH 및 ABTS 라디칼 소거활성은 시료 무첨 가구에 대한 시료첨가구의 흡광도비로 계산하여 \%로 나타 내었다.

FRAP(Ferric-reducing antioxidant power)에 의한 항산화 활성의 측정은 환원력을 이용한 방법으로 Benzie와 Strain 방법(31)을 응용하여 측정하였다. Sodium acetate buffer $(\mathrm{pH}$ $3.6,300 \mathrm{mM}$ )와 $40 \mathrm{mM} \mathrm{HCl}$ 에 용해시킨 $10 \mathrm{mM}$ 의 TPTZ(2,4,6-tripyridyl-s-triazine), $20 \mathrm{mM}$ 의 $\mathrm{FeCl}_{3} \cdot 6 \mathrm{H}_{2} \mathrm{O}$ 를 10:1:1의 비율로 혼합한 FRAP reagent $180 \mu \mathrm{L}$ 와 시료 추출 액 $6 \mu \mathrm{L}$ 를 혼합하고, 5 분간 방치한 후 분광광도계를 이용하 여 $595 \mathrm{~nm}$ 에서 흡광도를 측정하였고, $\mathrm{FeSO}_{4} \cdot 7 \mathrm{H}_{2} \mathrm{O}$ 를 사용 하여 환원력을 계산하였다.

\section{통계처리}

모든 실험은 3회 이상 반복하여 실시하였으며 실험으로 부터 얻은 결과는 SPSS 12.0(SPSS Inc., Chicago, IL, USA)

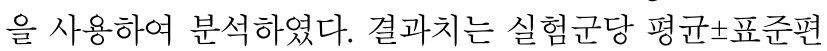
차로 표시하였고, 통계적 유의성 검정은 일원배치 분산분 석(one-way analysis of variance)을 한 후 $\mathrm{p}<0.05$ 수준에서 Duncan's multiple range test를 시행하였다.

\section{결과 및 고찰}

숙성단계에 따른 반시의 수분 변화

숙성단계에 따른 반시 미숙과의 수분함량(Table 2)은 step 1에서 $81.35 \pm 0.15 \%$ 었으며, 숙성이 진행됨에 따라 점차 
감소하여 step 7에서는 $80.19 \pm 0.20 \%$ 으로 숙성단계에 따른 수분 함량은 점차 감소하는 경향을 보였다. 완숙된 청도반 시의 수분 함량이 $77.52 \%$ 로 보고되고 있으며(7), 또한 성장 시기별 청도반시의 수분 함량은 $80 \sim 84 \%$ 로 수확시기가 늦 어질수록 수분 함량이 감소한다는 보고(32)도 있는데, 본 연구에 사용된 반시는 미숙과로 자체 수분이 $80 \%$ 이상으로 높아 숙성 후에도 $80 \%$ 이상의 높은 수분 함량을 유지한 것으로 판단된다.

수분 함량이 $60 \%$ 정도인 마늘을 숙성시켰을 때 숙성기간 과 온도가 증가할수록 수분 함량은 감소하며(33), 마늘을 숙성시켜 제조한 흑마늘과 홍마늘의 수분 함량은 각각 $53.42 \pm 0.62 \%$ 와 $32.52 \pm 1.52 \%$ 으로 생마늘의 수분 함량에 비 해 유의적으로 낮았고, 숙성기간이 경과함에 따라 수분 함 량은 더 감소하였다는 보고는 본 연구의 결과와도 일치하는 경향이며, 숙성 정도는 수분 함량에 영향을 미치는 주요 인자임을 알 수 있다(34,35).

Table 2. Changes of moisture content, $\mathrm{pH}$ and acidity on aging step in immature flat persimmon

\begin{tabular}{cccc}
\hline Aging step & Moisture (\%) & $\mathrm{pH}$ & Acidity $(\%)$ \\
\hline 1 & $81.35 \pm 0.15^{1)(\mathrm{C} 2)}$ & $6.44 \pm 0.091^{1) \mathrm{F} 2)}$ & $0.29 \pm 0.03^{\mathrm{A}}$ \\
2 & $81.15 \pm 0.69^{\mathrm{BC}}$ & $6.15 \pm 0.007^{\mathrm{E}}$ & $0.28 \pm 0.01^{\mathrm{A}}$ \\
3 & $81.10 \pm 0.35^{\mathrm{BC}}$ & $5.89 \pm 0.114^{\mathrm{D}}$ & $0.34 \pm 0.01^{\mathrm{B}}$ \\
4 & $80.55 \pm 0.17^{\mathrm{AB}}$ & $5.68 \pm 0.122^{\mathrm{C}}$ & $0.39 \pm 0.01^{\mathrm{C}}$ \\
5 & $80.48 \pm 0.59^{\mathrm{AB}}$ & $5.49 \pm 0.103^{\mathrm{B}}$ & $0.41 \pm 0.00^{\mathrm{C}}$ \\
6 & $80.15 \pm 0.05^{\mathrm{A}}$ & $5.27 \pm 0.122^{\mathrm{A}}$ & $0.46 \pm 0.01^{\mathrm{D}}$ \\
7 & $80.19 \pm 0.20^{\mathrm{A}}$ & $5.10 \pm 0.143^{\mathrm{A}}$ & $0.50 \pm 0.02^{\mathrm{E}}$ \\
\hline
\end{tabular}
${ }^{1)}$ Each value represents mean $\pm S D, n=3$.
${ }^{2)} A$-FMeans with different superscript in the same column are significantly different
at $p<0.05$.

\section{숙성단계에 따른 반시의 $\mathrm{pH}$ 및 산도 변화}

숙성에 따른 반시 미숙과의 $\mathrm{pH}$ 및 산도(Table 2)를 측정 한 결과, 숙성됨에 따라 $\mathrm{pH}$ 는 감소하고, 산도는 증가하는 경향을 보였는데 $\mathrm{pH}$ 는 step 1 에서 6.44 이던 것이 5.10 까지 감소하였고, 산도는 step 1 에서 $0.29 \%$ 이던 것이 step 7 에서 는 $0.50 \%$ 까지 증가하였다. 이러한 산도의 증가는 당/아미노 산의 비효소적 갈변반응 동안 열처리 온도와 기간이 증가할 수록 유기산 생성이 증가하였기(36) 때문으로 판단된다.

고려인삼을 열처리하여 생성된 갈변물질의 항산화 효능 을 확인한 Kim 등(37)의 연구에서도 당과 염기성 아미노산 의 결합에 의해 가용 염기성 아미노산의 감소 및 산성물질 의 생성으로 $\mathrm{pH}$ 가 감소된다고 보고되어 있다. 고온에서 마늘을 숙성시킬 경우 숙성 온도가 높을수록, 기간이 경과 할수록 $\mathrm{pH}$ 는 점차 산성화되며(34), Park 등(38)은 가온숙성 에 따른 건대추의 경우 지속적인 열분해로 인하여 단당류가 유기산 등으로 분해되어 산도가 증가한다고 보고하였다.
숙성단계에 따른 반시의 색도 변화

숙성단계에 따른 반시의 색도 변화(Table 3)는 육안으로 보았을 때 반시 미숙과가 숙성됨에 따라 황갈색에서 어두운 적색을 띄다가 점차 검은 색이 짙어짐을 확인할 수 있었다. 숙성에 따른 반시 미숙과의 명도(L)는 step 1 에서 67.77 이던 것이 갈변이 진행됨에 따라 점차 낮아져 최종 step 7에서는 31.71 까지 유의적으로 감소하였다. 적색도를 나타내는 a값 은 step 1 에는 6.48 이던 것이 step 2 에서는 3.13 으로 낮아졌 고 step 3에 17.56으로 급격히 증가하기 시작하여 step 4에서 19.37 으로 가장 높았다.

Table 3. Changes of Hunter's color value on aging step in immature flat persimmon

\begin{tabular}{cccc}
\hline Aging step & $\mathrm{L}$ & $\mathrm{a}$ & $\mathrm{b}$ \\
\hline 1 & $67.77 \pm 2.01^{1 / \mathrm{F} 2)}$ & $6.48 \pm 1.23^{\mathrm{B}}$ & $39.68 \pm 2.72^{\mathrm{C}}$ \\
2 & $42.54 \pm 1.78^{\mathrm{E}}$ & $3.13 \pm 0.86^{\mathrm{A}}$ & $20.41 \pm 2.98^{\mathrm{B}}$ \\
3 & $36.36 \pm 1.51^{\mathrm{D}}$ & $17.56 \pm 2.58^{\mathrm{C}}$ & $15.19 \pm 1.80^{\mathrm{A}}$ \\
4 & $35.09 \pm 1.55^{\mathrm{C}}$ & $19.37 \pm 0.91^{\mathrm{D}}$ & $15.83 \pm 1.16^{\mathrm{A}}$ \\
5 & $33.42 \pm 1.42^{\mathrm{B}}$ & $18.63 \pm 0.98^{\mathrm{D}}$ & $15.07 \pm 1.55^{\mathrm{A}}$ \\
6 & $32.96 \pm 1.82^{\mathrm{B}}$ & $17.48 \pm 1.22^{\mathrm{C}}$ & $15.35 \pm 1.48^{\mathrm{A}}$ \\
7 & $31.71 \pm 1.23^{\mathrm{A}}$ & $17.20 \pm 1.35^{\mathrm{C}}$ & $14.70 \pm 1.31^{\mathrm{A}}$ \\
\hline
\end{tabular}

${ }^{1)}$ Each value represents mean $\pm \mathrm{SD}, \mathrm{n}=18$.

2)A-F Means with different superscript in the same column are significantly different at $\mathrm{p}<0.05$.

색도 측정항목 중 갈변 정도를 나타내어 식품의 중요한 품질지표로 작용(39)하는 황색도를 나타내는 b값은 step 1 에서 39.68이었으나 step 2에서 20.41으로 감소폭이 컸으 며 이후 숙성됨에 따라 15.19 14.70의 범위로 유사한 값을 나타내면서 숙성기간에 따른 유의적인 차이를 보이지 않았 다. 숙성 초기 반시의 황색도가 급격히 증가한 이유는 열처 리 가공을 통해 식품 자체의 색이 점차 갈색으로 변하는 갈변화 반응이 숙성 초기에 활발히 일어났기 때문으로 판단 된다. 홍삼 제조 시, 인삼은 $60^{\circ} \mathrm{C}$ 이상의 증숙 과정을 거치면 서 효소적 및 비효소적 갈변반응이 진행되는데 이 중 비효 소적 갈변반응이 갈색화의 주된 작용으로 보고되어 있어 (40), 본 실험에서도 반시 미숙과가 $70^{\circ} \mathrm{C}$ 에서의 숙성과정을 거치면서 비효소적 갈변반응이 일어나 색도의 변화에 영향 을 미치는 것으로 확인되었다.

식품에서의 변색은 매우 중요한 품질변화 요인 중의 하 나로(41) 갈변화 반응은 수분손실, $\mathrm{PPO}$ 의 촉매작용, 숙성, 부패, $\mathrm{pH}$, 비타민 $\mathrm{C}$ 함량, 온도 등과 같은 다양한 요인에 의해 영향을 받을 수 있다(42).

\section{숙성단계에 따른 반시의 조직감 변화}

반시가 숙성됨에 따라 나타나는 조직감의 변화는 Table 4에 나타내었다. 식품의 단단함 정도를 나타내는 hardness 
(경도)의 경우, 숙성기간이 경과할수록 유의적으로 감소하 는 경향을 나타내었다(Table 4). 즉, step 1에서 반시 미숙과 의 경도는 $979.06 \mathrm{~g}$ 이었는데, step 2의 반시 경도가 699.63 $\mathrm{g}$ 로 감소하였고, 이후 숙성됨(step3 7)에 따라 97.70 68.68 $\mathrm{g}$ 까지 감소하였다. 온도를 달리하여 마늘을 숙성시킨 홍마 늘(33)과 흑마늘(34)의 경도 변화를 분석한 결과, 숙성 초기 에는 열에 의해 마늘의 육질부가 물러지는 현상을 보였고, 숙성기간이 경과함에 따라 수분이 감소되어 육질이 단단해 짐에 따라 경도가 증가하였다. 본 실험에서도 동일하게 반 시 미숙과의 경도가 step 2에서 step 3사이에 7배로 급격히 감소하여 숙성 초기 조건에서의 경도의 감소폭이 컸으며, 숙성 중·후기로 갈수록 적었다. 이때 저장 온도가 높을수록 호흡율 및 갈변진행이 증가하여 과육경도의 감소가 증가한 다고 보고되어 있다(40). Springiness(탄력성)은 step 1에서 0.71 로 가장 낮았고 step 2에서 0.87 로 증가하였다가 이후 부터는 숙성 정도에 따른 유의적인 차이가 보이지 않아 숙성 온도를 적당히 높였을 때 반시의 탄력성은 더 증가하 는 것으로 판단된다. Chewiness(씹힘성)과 gumminess(점착 성)는 반시가 숙성됨에 따라 감소하는 경향을 나타내었으 며, step 2에서 step 3로 넘어가는 단계에 감소폭이 컸고 그 이후에는 유의적인 차이가 없었다.

Table 4. Changes of texture characteristic on aging step in immature flat persimmon

\begin{tabular}{ccccc}
\hline Aging step & Hardness (g) & Springiness & Chewiness & Gumminess \\
\hline 1 & $979.06 \pm 34.46^{1 \mathrm{DD} 2)}$ & $0.71 \pm 0.15^{\mathrm{A}}$ & $232.11 \pm 58.80^{\mathrm{C}}$ & $324.62 \pm 36.64^{\mathrm{C}}$ \\
2 & $699.63 \pm 40.04^{\mathrm{C}}$ & $0.87 \pm 0.11^{\mathrm{B}}$ & $207.79 \pm 60.47^{\mathrm{B}}$ & $237.77 \pm 57.87^{\mathrm{B}}$ \\
3 & $97.70 \pm 24.35^{\mathrm{B}}$ & $0.91 \pm 0.10^{\mathrm{B}}$ & $25.33 \pm 7.06^{\mathrm{A}}$ & $27.61 \pm 6.34^{\mathrm{A}}$ \\
4 & $89.04 \pm 13.69^{\mathrm{B}}$ & $0.88 \pm 0.16^{\mathrm{B}}$ & $23.26 \pm 7.11^{\mathrm{A}}$ & $26.31 \pm 7.11^{\mathrm{A}}$ \\
5 & $72.08 \pm 9.47^{\mathrm{A}}$ & $0.89 \pm 0.10^{\mathrm{B}}$ & $19.75 \pm 5.05^{\mathrm{A}}$ & $21.97 \pm 4.44^{\mathrm{A}}$ \\
6 & $69.56 \pm 10.03^{\mathrm{A}}$ & $0.89 \pm 0.15^{\mathrm{B}}$ & $21.48 \pm 7.13^{\mathrm{A}}$ & $23.65 \pm 6.72^{\mathrm{A}}$ \\
7 & $68.68 \pm 9.55^{\mathrm{A}}$ & $0.92 \pm 0.07^{\mathrm{B}}$ & $19.19 \pm 3.77^{\mathrm{A}}$ & $20.77 \pm 3.43^{\mathrm{A}}$ \\
\hline
\end{tabular}

${ }^{1)}$ Each value represents mean $\pm \mathrm{SD}, \mathrm{n}=17$.

2)A-D Means with different superscript in the same column are significantly different at $\mathrm{p}<0.05$.

\section{숙성단계에 따른 반시의 유리당 함량 변화}

숙성단계에 따른 반시 미숙과의 유리당 함량을 분석한 결과는 Table 5 와 같이, 숙성단계에 따라 fructose의 함량은 감소하였으며 glucose의 함량은 증가하였다. Step 1에서의 fructose 함량은 $4.42 \pm 0.07 \mathrm{~g} / 100 \mathrm{~g}$ 이었으나, step 2에서 증가 하였다가 step 3 이후부터는 점차 감소하여 최종 단계에서 $2.93 \pm 0.31 \mathrm{~g} / 100 \mathrm{~g}$ 이었다. Glucose 함량은 step 4까지는 유의 차 없이 미량씩 증가하였으나 step 5에서 $7.60 \pm 0.64 \mathrm{~g} / 100$

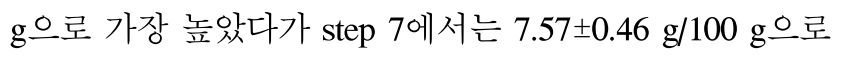
step 1 에 비해 1.25 배 더 증가하였다.

열처리한 고려홍삼과 인삼의 경우에도 주요 유리당은 fructose와 glucose이었으며, 열처리 온도가 증가함에 따라 전체 유리당 함량은 감소하였으나 fructose와 glucose의 함 량은 증가하는데, 이는 고온에서 이당류인 sucrose가 단당 류인 fructose와 glucose로 분해되기 때문이라는 Hwang 등 (43)과 Lee 등(44)의 보고가 있다. 열처리 시 glucose와 fructose가 maillard 반응 및 caramelization 반응과 같은 비효 소적 갈변반응에 관여하여 유리당의 함량에 변화가 생기는 데, glucose보다 fructose의 감소량이 더 크게 나타나는 것은 glucose보다 fructose가 반응성이 높기 때문으로 알려져 있 다(45). 본 연구에서도 fructose의 함량은 감소한데 반해 glucose 함량은 미량 증가하였는데, 이는 숙성과정 중 이당 류가 분해되고, 반응성이 큰 fructose가 빠르게 갈변화 반응 에 참여하기 때문으로 추정된다.

Table 5. Changes of free sugar content on aging step in immature flat persimmon

$(\mathrm{g} / 100 \mathrm{~g})$

\begin{tabular}{ccc}
\hline Aging step & Fructose & Glucose \\
\hline 1 & $4.42 \pm 0.07^{1)(2)}$ & $6.04 \pm 0.15^{\mathrm{A}}$ \\
2 & $4.87 \pm 0.22^{\mathrm{D}}$ & $6.23 \pm 0.47^{\mathrm{A}}$ \\
3 & $4.18 \pm 0.28^{\mathrm{C}}$ & $6.52 \pm 0.12^{\mathrm{AB}}$ \\
4 & $3.35 \pm 0.06^{\mathrm{B}}$ & $6.59 \pm 0.71^{\mathrm{AB}}$ \\
5 & $3.36 \pm 0.27^{\mathrm{B}}$ & $7.60 \pm 0.64^{\mathrm{C}}$ \\
6 & $3.07 \pm 0.06^{\mathrm{AB}}$ & $7.08 \pm 0.09^{\mathrm{BC}}$ \\
7 & $2.93 \pm 0.31^{\mathrm{A}}$ & $7.57 \pm 0.46^{\mathrm{C}}$ \\
\hline
\end{tabular}

1) Each value represents mean $\pm \mathrm{SD}, \mathrm{n}=3$.
2)-D Means with different superscript in the same column are significantly different at $\mathrm{p}<0.05$.

숙성단계에 따른 반시의 항산화 물질의 함량 변화

숙성단계에 따른 반시의 페놀성 화합물, 플라보노이드 및 탄닌 함량을 나타낸 결과는 Table 6과 같으며, 페놀성 화합물은 식물계에 분포된 2 차 대사산물 중 하나로 감잎과 감과실에는 다양한 페놀성 물질이 함유되어 있는데, 이들 성분은 각종 질병의 원인이 되는 활성산소를 억제하는 능력 이 뛰어난 것으로 알려져 있어 감은 항알레르기성, 항돌연 변이 및 항산화성 등의 효과를 가지며 플라보노이드는 식물 에 널리 존재하며 주로 색을 나타내는 화합물로 페놀성 화합물과 함께 체내에 유효한 효능을 나타낸다 $(16,46)$. 탄 닌은 감 과실류의 주요 페놀성 성분인데 강한 수렴작용을 지녀 위궤양, 설사와 같은 소화기 질환에 좋고, 지혈작용이 있어 뇌출혈 증세 및 모세혈관 강화작용으로 인한 고혈압과 같은 순환기계 질환의 예방과 치료에 매우 우수하다고 보고 된 바 있다(12). 감 과실류에 존재하는 탄닌은 기본구조가 catechin과 gallocatechin 등을 골격으로 한 proanthocyanidin 의 polymer로서 그 측쇄에 gallic acid가 ester 결합을 한 것으로 밝혀져 있다(47). 
Table 6. Changes of antioxidant compound content on aging step in immature flat persimmon

\begin{tabular}{|c|c|c|c|c|}
\hline \multirow{2}{*}{$\begin{array}{l}\text { Aging } \\
\text { step }\end{array}$} & \multirow{2}{*}{$\begin{array}{l}\text { Flavonoid } \\
\text { content } \\
(\mathrm{mg} / 100 \mathrm{~g})\end{array}$} & \multicolumn{2}{|c|}{ Phenolic compound content $(\mathrm{mg} / \mathrm{g})$} & \multirow{2}{*}{$\begin{array}{l}\text { Tannin acid content } \\
\text { (mg tannin acid } \\
\text { equivalent } \\
(\mathrm{TAE} / 100 \mathrm{~g})\end{array}$} \\
\hline & & Gallic acid & $\begin{array}{l}\text { Homogentisic } \\
\text { acid }\end{array}$ & \\
\hline 1 & $17.31 \pm 0.05^{\left.1 / \mathrm{F}^{2}\right)}$ & $\mathrm{ND}^{3)}$ & ND & $287.61 \pm 0.06^{\mathrm{F}}$ \\
\hline 2 & $5.22 \pm 0.05^{\mathrm{B}}$ & $\mathrm{ND}$ & ND & $17.59 \pm 0.13^{A}$ \\
\hline 3 & $4.14 \pm 0.05^{\mathrm{A}}$ & $0.19 \pm 0.02^{\mathrm{A}}$ & $0.12 \pm 0.01^{\mathrm{A}}$ & $60.99 \pm 0.04^{\mathrm{B}}$ \\
\hline 4 & $5.75 \pm 0.05^{\mathrm{B}}$ & $0.23 \pm 0.01^{B}$ & $0.20 \pm 0.01^{B}$ & $83.84 \pm 0.06^{\mathrm{E}}$ \\
\hline 5 & $6.29 \pm 0.00^{\mathrm{C}}$ & $0.24 \pm 0.00^{B C}$ & $0.29 \pm 0.00^{\mathrm{C}}$ & $80.06 \pm 0.06^{\mathrm{D}}$ \\
\hline 6 & $8.44 \pm 0.05^{\mathrm{D}}$ & $0.26 \pm 0.02^{\mathrm{C}}$ & $0.55 \pm 0.04^{\mathrm{D}}$ & $72.94 \pm 0.04^{\mathrm{C}}$ \\
\hline 7 & $9.52 \pm 0.00^{\mathrm{E}}$ & $0.28 \pm 0.00^{\mathrm{D}}$ & $0.96 \pm 0.01^{\mathrm{E}}$ & $73.14 \pm 0.06^{\mathrm{C}}$ \\
\hline
\end{tabular}

${ }^{1)}$ Each value represents mean $\pm \mathrm{SD}, \mathrm{n}=3$.

2)A-F Means with different superscript in the same column are significantly different at $p<0.05$.

${ }^{3} \mathrm{ND}$, means not detected.

페놀성 물질의 함유에 의한 감과실의 가치는 성장이 진 행됨에 따라 감소하고, 단감에 비하여 떫은 감이 성장 중 모든 단계에서 탄닌 함량이 높다고 보고되어 있다(47). 숙성 단계에 따른 반시 미숙과의 페놀 화합물로는 gallic acid와 homogentisic acid 2종이 검출되었는데, 이들 화합물은 step 2 까지는 검출되지 않았으나, step 3 에서는 각각 $0.19 \pm 0.02$ $\mathrm{mg} / \mathrm{g}$ 과 $0.12 \pm 0.01 \mathrm{mg} / \mathrm{g}$ 의 함량을 나타내었고, 숙성단계가 지남에 따라 함량이 증가하여 step 7에서는 각각 $0.28 \pm 0.00$ $\mathrm{mg} / \mathrm{g}, 0.96 \pm 0.01 \mathrm{mg} / \mathrm{g}$ 이었다. Lee 등(32)은 청도반시에서 페놀산으로 chlorogenic acid, caffeic acid, p-coumaric acid 및 salicylic acid 등이 확인 되었다고 보고하였는데, 본 실험 의 결과에서는 gallic acid와 homogentisic acid만이 검출된 것은 과실의 성숙정도 차이로 판단된다.

반시 미숙과의 숙성에 따른 플라보노이드는 step 1 에서 $17.31 \pm 0.05 \mathrm{mg} / 100 \mathrm{~g}$ 이었다가 숙성단계가 지남에 따라 감 소하여 step 3에서 $4.14 \pm 0.05 \mathrm{mg} / 100 \mathrm{~g}$ 으로 4 배 이상 감소한 후 step 4 부터는 유의적으로 증가하여 step 7에서 $9.52 \pm 0.00$ $\mathrm{mg} / 100 \mathrm{~g}$ 이었다. 숙성단계에 따른 반시의 탄닌 함량을 살펴 본 결과, step 1 만 거친 시료의 탄닌 함량이 $287.61 \mathrm{mg} \operatorname{tannin}$ acid equivalent(TAE)/100 g으로 가장 높게 측정되었고, step 2 를 거치면서 $17.59 \mathrm{TAE} / 100 \mathrm{~g}$ 으로 급감하여 숙성단계 중 가장 낮았다. 한편 step 3에서는 탄닌 함량이 반등하는 결과 를 보이면서 step 3과 4에서 각각 $60.99 \mathrm{TAE} / 100 \mathrm{~g}$ 과 83.84 $\mathrm{TAE} / 100 \mathrm{~g}$ 을 나타내었다. 이후 숙성단계의 경과에 따라 다시 감소하여 step 5 7의 탄닌 함량은 72.94 80.06 $\mathrm{TAE} / 100 \mathrm{~g}$ 이었다. Seong과 $\mathrm{Han}(47)$ 은 떫은 감의 탄닌 함량 이 9월 이후 감소한다고 보고하였는데, 그 원인으로 과실의 비대속도가 탄닌의 축적 속도보다 크고, 과실의 성숙기에 alcohol dehydrogenase의 작용으로 생성된 acetaldehyde 등 의 영향으로 가용성 탄닌 물질이 불용화된 것으로 추정하였 다. 본 연구에서는 반시에 열처리를 가해 숙성시킨 단계 중 step 2 의 탄닌 함량이 step 1 의 $16 \%$ 수준으로 크게 감소하

Table 7. Changes of antioxidant activity on aging step in immature flat persimmon

\begin{tabular}{|c|c|c|c|c|c|c|c|c|}
\hline \multirow{2}{*}{ Items } & \multirow{2}{*}{$\begin{array}{c}\text { Concentration } \\
(\mu \mathrm{g} / \mathrm{mL})\end{array}$} & \multicolumn{7}{|c|}{ Aging step } \\
\hline & & 1 & 2 & 3 & 4 & 5 & 6 & 7 \\
\hline \multirow{5}{*}{$\begin{array}{l}\text { DPPH radical scavenging } \\
\text { ability } \\
(\%)\end{array}$} & 62.5 & $28.23 \pm 1.33^{1 \mathrm{DD} 2) \mathrm{a} 3)}$ & $21.54 \pm 0.32^{\mathrm{Aa}}$ & $25.69 \pm 1.99^{\mathrm{Ca}}$ & $25.35 \pm 0.15^{\mathrm{Ca}}$ & $24.37 \pm 1.03^{\mathrm{BCa}}$ & $24.61 \pm 0.44^{\mathrm{BCa}}$ & $23.16 \pm 0.87^{\mathrm{Ba}}$ \\
\hline & 125 & $38.44 \pm 1.24^{\mathrm{Eb}}$ & $25.85 \pm 0.50^{\mathrm{Ab}}$ & $32.06 \pm 1.42^{\mathrm{Db}}$ & $31.52 \pm 0.71^{\mathrm{CDb}}$ & $29.95 \pm 1.50^{\mathrm{BCb}}$ & $31.19 \pm 0.92^{\mathrm{CDb}}$ & $28.53 \pm 0.72^{\mathrm{Bb}}$ \\
\hline & 250 & $53.30 \pm 0.77^{\mathrm{Ec}}$ & $33.56 \pm 0.51^{\mathrm{Ac}}$ & $41.54 \pm 1.02^{\mathrm{Dc}}$ & $40.75 \pm 0.96^{\mathrm{CDc}}$ & $39.72 \pm 1.20^{\mathrm{Cc}}$ & $40.52 \pm 0.56^{\mathrm{CDc}}$ & $37.81 \pm 1.53^{\mathrm{Bc}}$ \\
\hline & 500 & $71.10 \pm 1.47^{\mathrm{Dd}}$ & $47.49 \pm 0.77^{\mathrm{Ad}}$ & $57.07 \pm 1.52^{\mathrm{Cd}}$ & $56.25 \pm 1.28^{\mathrm{Cd}}$ & $56.55 \pm 1.47^{\mathrm{Cd}}$ & $55.69 \pm 1.09^{\mathrm{Cd}}$ & $51.20 \pm 0.98^{\mathrm{Bd}}$ \\
\hline & 1000 & $80.21 \pm 0.35^{\mathrm{Ee}}$ & $65.91 \pm 1.18^{\mathrm{Ae}}$ & $76.45 \pm 1.09^{\mathrm{De}}$ & $75.96 \pm 1.11^{\mathrm{CDe}}$ & $76.67 \pm 1.20^{\mathrm{De}}$ & $74.55 \pm 0.85^{\mathrm{Ce}}$ & $71.29 \pm 1.33^{\mathrm{Be}}$ \\
\hline \multirow{5}{*}{$\begin{array}{l}\text { ABTS radical scavenging } \\
\text { ability } \\
(\%)\end{array}$} & 62.5 & $28.39 \pm 1.42^{\mathrm{Da}}$ & $14.91 \pm 0.77^{\mathrm{Aa}}$ & $19.19 \pm 0.81^{\mathrm{Ca}}$ & $17.92 \pm 1.40^{\mathrm{BCa}}$ & $17.76 \pm 0.57^{\mathrm{BCa}}$ & $16.51 \pm 1.27^{\mathrm{Ba}}$ & $17.70 \pm 0.15^{\mathrm{BCa}}$ \\
\hline & 125 & $51.57 \pm 1.17^{\mathrm{Db}}$ & $26.05 \pm 1.81^{\mathrm{Ab}}$ & $31.31 \pm 1.75^{\mathrm{Cb}}$ & $32.45 \pm 0.31^{\mathrm{Cb}}$ & $32.32 \pm 1.22^{\mathrm{Cb}}$ & $28.52 \pm 1.55^{\mathrm{Bb}}$ & $26.79 \pm 1.63^{\mathrm{ABb}}$ \\
\hline & 250 & $87.23 \pm 1.00^{\mathrm{Ec}}$ & $45.52 \pm 1.22^{\mathrm{Ac}}$ & $57.71 \pm 1.12^{\mathrm{Dc}}$ & $53.06 \pm 0.77^{\mathrm{Cc}}$ & $56.64 \pm 0.96^{\mathrm{Dc}}$ & $51.97 \pm 0.40^{\mathrm{Cc}}$ & $48.83 \pm 0.99^{\mathrm{Bc}}$ \\
\hline & 500 & $99.08 \pm 0.09^{\mathrm{Fd}}$ & $77.59 \pm 0.66^{\mathrm{Ad}}$ & $93.16 \pm 0.65^{\mathrm{Ed}}$ & $90.26 \pm 0.15^{\mathrm{Dd}}$ & $90.39 \pm 0.23^{\mathrm{Dd}}$ & $86.01 \pm 1.97^{\mathrm{Cd}}$ & $82.00 \pm 0.80^{\mathrm{Bd}}$ \\
\hline & 1000 & $99.25 \pm 0.00^{\mathrm{Dd}}$ & $98.98 \pm 0.06^{\mathrm{Be}}$ & $99.17 \pm 0.07^{\mathrm{CDe}}$ & $99.15 \pm 0.06^{\mathrm{CDe}}$ & $99.06 \pm 0.06^{\mathrm{BCe}}$ & $99.05 \pm 0.10^{\mathrm{BCe}}$ & $98.83 \pm 0.00^{\mathrm{Ae}}$ \\
\hline \multirow{5}{*}{$\begin{array}{c}\text { FRAP } \\
\left(\mathrm{FeSO}_{4} \cdot 7 \mathrm{H}_{2} \mathrm{O} \text { eq } \mu \mathrm{M}\right)\end{array}$} & 62.5 & $16.15 \pm 0.33^{\mathrm{Ea}}$ & $3.78 \pm 0.58^{\mathrm{Aa}}$ & $6.39 \pm 0.22^{\mathrm{Ca}}$ & $7.27 \pm 0.98^{\mathrm{Da}}$ & $7.03 \pm 0.29^{\mathrm{CDa}}$ & $5.44 \pm 0.37^{\mathrm{Ba}}$ & $3.06 \pm 0.24^{\mathrm{Aa}}$ \\
\hline & 125 & $37.84 \pm 1.27^{\mathrm{Db}}$ & $13.00 \pm 0.23^{\mathrm{Ab}}$ & $18.68 \pm 0.81^{\mathrm{Bb}}$ & $18.72 \pm 0.96^{\mathrm{Bb}}$ & $21.10 \pm 0.94^{\mathrm{Cb}}$ & $18.55 \pm 0.45^{\mathrm{Bb}}$ & $12.00 \pm 0.29^{\mathrm{Ab}}$ \\
\hline & 250 & $82.06 \pm 1.52^{\mathrm{Fc}}$ & $31.30 \pm 0.65^{\mathrm{Bc}}$ & $44.22 \pm 1.85^{\mathrm{Dc}}$ & $43.19 \pm 0.66^{\mathrm{Dc}}$ & $47.90 \pm 0.61^{\mathrm{Ec}}$ & $41.51 \pm 0.49^{\mathrm{Cc}}$ & $29.77 \pm 0.49^{\mathrm{Ac}}$ \\
\hline & 500 & $171.52 \pm 0.82^{\mathrm{Fd}}$ & $68.12 \pm 0.69^{\mathrm{Bd}}$ & $92.07 \pm 0.96^{\mathrm{Dd}}$ & $91.18 \pm 0.54^{\mathrm{Dd}}$ & $100.86 \pm 1.29^{\mathrm{Ed}}$ & $89.18 \pm 0.75^{\mathrm{Cd}}$ & $64.32 \pm 1.82^{\mathrm{Ad}}$ \\
\hline & 1000 & $345.68 \pm 3.46^{\mathrm{Ge}}$ & $143.47 \pm 2.04^{\mathrm{Be}}$ & $190.96 \pm 1.43^{\mathrm{Ee}}$ & $186.31 \pm 1.04^{\mathrm{De}}$ & $208.27 \pm 3.72^{\mathrm{Fe}}$ & $180.38 \pm 3.48^{\mathrm{Ce}}$ & $136.90 \pm 1.89^{\mathrm{Ae}}$ \\
\hline
\end{tabular}

${ }^{1)}$ Each value represents mean $\pm S D, n=4$.

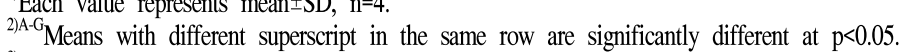

${ }^{3) a-e}$ Means with different superscript in the same column are significantly different at $p<0.05$. 
였다. 이는 $90^{\circ} \mathrm{C}$ 에 이르는 높은 온도 처리로 인하여 가용성 탄닌 물질들이 갈변반응에 관여하는 당류와 아미노산과 일시적으로 결합하였다가 숙성 정도가 진행됨에 따라 이들 이 갈변 반응에 참여함으로써 다시 유리되어 검출량에 차이 가 발생한 것으로 추정된다. 하지만 이와 관련하여서는 정 확한 메커니즘 규명을 위한 추후 연구가 더 진행되어야 할 것으로 판단된다.

\section{숙성단계에 따른 반시 물 추출물의 항산화 활성}

숙성단계별 시료의 물 추출물을 제조한 후 이를 동결 건조하여 $\mathrm{DPPH}$ 와 $\mathrm{ABTS}$ 라디칼 소거능 및 FRAP법에 따른 항산화 활성을 각각 측정한 결과는 Table 7에 나타내었다. 시료의 항산화 활성은 농도에 비례하여 유의적으로 증가하 는 경향을 보였으며, 숙성단계에 따라서는 $70^{\circ} \mathrm{C}$ 에서 12 시 간 숙성시킨 step 1 에서 가장 높은 항산화 활성을 보였는데, $\mathrm{DPPH}$ 라디칼 소거능과 $\mathrm{ABTS}$ 라디칼 소거능은 각각 250 , $125 \mathrm{\mu g} / \mathrm{mL}$ 농도에서 $50 \%$ 이상의 활성을 보였다. 또한 FRAP법에 의거하여 측정한 항산화 활성 역시 step 1시료의 항산화 활성이 모든 농도군에서 가장 높은 활성을 나타내었 다. FRAP는 숙성기간의 경과와 더불어 불규칙한 증감을 나타내었는데, $250 \mathrm{\mu g} / \mathrm{mL}$ 의 농도에서 step 1은 $82.0 \pm 61.52$ $\mu \mathrm{M}$ 이던 것이 step 2에서 $31.30 \pm 0.65 \mu \mathrm{M}$ 로 활성이 오히려 감소하였으나, step 3이후부터는 다시 활성이 증가하여 step 6 까지 $41.51 \pm 0.49 \sim 47.90 \pm 0.61 \mu \mathrm{M}$ 의 범위였다.

통마늘을 고온 항온기에 일정시간 숙성시키면서 제조한 흑마늘의 단계별 항산화 활성은 마늘의 숙성이 진행될수록 시료의 농도가 높을수록 높아지는데, 이는 숙성이 진행될 수록 갈변물질의 생성량이 점진적으로 증가하게 되어 항산 화 활성을 가지는 고분자의 melanoidin 화합물이 더 많이 축적되었기 때문으로 보고되어 있다(35). 숙성 반시에서는 이와 상반되게 숙성이 진행될수록 항산화 활성은 오히려 감소하였는데, 흑마늘의 경우는 숙성의 진행과 더불어 페 놀성 화합물이 증가하지만, 본 연구에 사용된 미숙성 반시 의 경우 숙성이 진행될수록 페놀 화합물이나 탄닌의 함량이 상대적으로 감소하기 때문에 항산화 활성이 오히려 낮아진 것으로 판단된다.

\section{요 약}

미숙과의 가공법 제안 및 기능성 규명을 위한 기초 연구 의 일환으로 반시 미숙과를 $7 \mathrm{step}$ 으로 나누어 열처리 숙성 하면서 이화학적 특성 및 항산화 활성의 변화를 분석하였 다. 반시 미숙과는 숙성됨에 따라 수분함량과 $\mathrm{pH}$ 는 점차 감소하고, 산도는 증가하는 경향이었다. 숙성이 진행됨에 따라 갈변이 유도되면서 step 3까지 적색도는 급격히 증가 하였으며, 황색도는 큰 폭으로 감소하였다. 반시의 탄력성, 씹힘성과 점착성의 경우에는 step 2 3에서 변화한 후에는
유의적인 차이를 보이지 않았다. 숙성 중 반시 미숙과의 fructose의 함량은 감소한데 반해 glucose 함량은 미량 증가 하였다. 페놀성 화합물은 gallic acid와 homogentisic acid, 2종이 검출되었는데 이들 화합물은 step 2까지는 검출되지 않았으나, step 3 부터 숙성단계가 지남에 따라 함량이 증가 하였다. 이와 상반되게 탄닌 함량은 step 1 에서 가장 높게 측정되었고 step 2에서 급감하였다. 숙성 단계별 반시 미숙 과 물 추출물의 DPPH와 $\mathrm{ABTS}$ 라디칼 소거능 및 FRAP법 에 따른 항산화 활성은 시료의 농도에 비례하여 유의적으로 증가하였으나, 숙성이 진행될수록 오히려 낮아졌다.

\section{References}

1. Lee SJ, Shin JH, Kang MJ, Jung WJ, Ryu JH, Kim RJ, Sung NJ (2010) Antioxidants activity of aged red garlic. J Life Sci, 20, 775-781

2. Shin JH, Choi DJ, Lee SJ, Cha JY, Sung NJ (2008) Antioxidant activity of black garlic (Allium sativum L.). J Korean Soc Food Sci Nutr, 37, 965-971

3. Lee JW, Ko HR, Shim KH (1998) Structural characteristics of the water soluble browning reaction products isolated from Korean red ginseng. Korean $\mathbf{J}$ Food Nutr, 11, 499-505

4. Lee JW, Do JH (2006) Current studies on browning reaction products and acidic polysaccharide in Korean red ginseng. J Ginseng Res, 30, 41-48

5. Heo BG, Park YJ, Kim TC, Kim HJ, Park SM, Kim KS, Jang HG, Lee KD, Yun JG (2009) Chemical characteristics, antimicrobial activity and dye ability of Gyeongsanbansi (persimmon kaki) unripe juice extraction and fermented liquor. Korean J Plant Res, 22, 438-445

6. Kim HJ, Park TS, Jung MS, Son JH (2011) Study on the antioxidant and anti-inflammatory activities of sarcocarp and calyx of persimmon (Chenogdo bansi). J Appl Biol Chem, 54, 71-78

7. Lee SW, Lee OS, Jang SY, Jeong YJ, Kwon JH (2006) Monitoring of alcohol fermentation condition for 'Cheongdobansi' astringent persimmon (Diosyros kaki t.). Korean J Food Preserv, 13, 490-494

8. Seo JH, Jeong YJ, Kim KS (2000) Physiological characteristics of tannin isolated from astringent persimmon fruits. Korean J Food Sci Technol, 32, 212-217

9. Roh YK, Jang SH, Park SH, Byun HS, Sung JJ (1999) Analysis of distribution properties on astringent persimmons (Diospyros kaki L.). Korean J Postharvest Sci Technol, 6, 184-187 
10. Jeong YJ, Lee GD, Kim KS (1998) Optimization for the fermentation condition of persimmon vinegar using response surface methodology. Korean J Food Sci Technol, 30, 1203-1208

11. Seong JH, Goo MS, Chung HS (2008) Changes of quality and astringency of persimmons due to modified atmosphere packaging. Korean J Food Preserv, 15, 225-230

12. Heo JC, Chae JH, Lee SH, Lee YR, Moon KD, Chung SK, Lee SH (2008) Comparison of radical scavenging and immunomodulatory activities exhibited by an aqueous extract of Diospyros kaki Thunb. fruit (Persimmon). Korean J Food Preserv, 15, 749-753

13. Koh JY, Kim KB, Choi SK (2013) Quality characteristics of Gochujang containing various amounts of persimmon syrup. Culinary Science Hospitality Research, 19, $139-150$

14. Shin DS, Kim KM, Han SY, Han GJ (2013) Changes in the quality characteristics of Sulgidduk by the addition of persimmon peel. Korean J Food Cook Sci, 29, 479-487

15. Jeong SI, Cho JK, Mok JY, Kim SJ, Park JM, Jeon IH, Kim HS, Jang SI (2010) Antioxidant activity of persimmon leaves during growth. Kor J Pharmacogn, 41, 255-263

16. Yoo KH, Kim SJ, Jeong JM (2011) Effects of persimmon (Diospyros kaki Thunb) syrup extracted from persimmon and persimmon by-products on blood glucose level. J Korean Soc Food Sci Nutr, 40, 682-688

17. Chung JY, Kim KH, Shin DJ, Son GM (2002) Effects of sweet persimmon powder on the characteristics of bread. J Korean Soc Food Sci Nutr, 31, 738-742

18. Shin DS, Park HY, Kim MH, Han GJ (2011) Quality characteristics of bread with persimmon peel powder. Korean J Food Cook Sci, 27, 589-597

19. Hong JS, Kim MA (2005) Quality characteristics of Sulgiduck by the addition of astringency persimmon paste. Korean J Food Cook Sci, 21, 360-370

20. Lee YR, Chung HS, Seong JH, Moon KD (2011) Effect of different coagulants on quality of tofu incorporated with persimmon fruit powder. Korean J Food Preserv, $18,678-683$

21. Choi HY (2013) Antioxidant activity and quality characteristics of mung bean starch gel prepared with persimmon powder. Korean J Food Nutr, 26, 638-645

22. Bae SM, Park KJ, Kim JM, Shin DJ, Hwang YI, Lee SC (2002) Preparation and characterization of sweet persimmon wine. J Korean Soc Agric Chem Biotechnol,
45, 66-70

23. Park WK, Yoo YH, Hyun JS (1975) Study on the manufacture of jam with Korean persimmon. J Korean Soc Food Sci Nutr, 4, 25-29

24. Kang YJ, Yang MH, Ko WJ, Park SR, Lee BG (2005) Studies on the major components and antioxidative properties of whole fruit powder and juice prepared from premature mandarin orange. Korean J Food Sci Technol, 37, 783-788

25. Yi MR, Hwang JH, Oh YS, Oh HJ, Lim SB (2014) Quality characteristics and antioxidant activity of immature Citrus unshiu vinegar. J Korean Soc Food Sci Nutr, 43, 250-257

26. Seo JH, Jeong YJ, Shin SR, Kim JN, Kim KS (1999) Changes in pattern of tannin isolated from astringent persimmon fruits. Korean J Food Preserv, 6, 328-332

27. Moreno MIN, Isla MIN, Sampietro AR, Vattuone MA (2000) Comparison of the free radical scavenging activity of propolis from several region of Argentina. J Enthnopharmacology, 71, 109-114

28. Duval B, Shetty K (2001) The stimulation of phenolics and antioxidant activity in pea (Pisum sativum) elicited by genetically transformed anise root extract. J Food Biochem, 25, 361-377

29. Blois MS (1958) Antioxidant determination by the use of a stable free radical. Nature, 181, 1199-1200

30. Re R, Pellegrini N, Proteggente A, Pannala A, Yang M, Rice-Evans C (1999) Antioxidant activity applying an improved ABTS radical cation decolorization assay. Free Radic Biol Med, 26, 1231-1237

31. Benzie IFF, Strain JJ (1996) The ferric reducing ability of plasma (FRAP) as a measure of "antioxidant power": The FRAP assay. Anal Biochem, 239, 70-76

32. Lee YR, Chung HS, Moon KD (2011) Change in the polyphenol content of Cheongdobansi persimmon fruit during development. Korean J Food Preserv, 18, 13-17

33. Kang MJ, Yoon HS, Jeong SH, Sung NJ (2011) Physicochemical characteristics of red garlic during processing. Korean J Food Preserv, 18, 898-906

34. Shin JH, Choi DJ, Chung MJ, Kang MJ, Sung NJ (2008) Changes of physicochemical components and antioxidant activity of aged garlic at different temperature. J Korean Soc Food Sci Nutr, 37, 1174-1181

35. Shin JH, Choi DJ, Lee SJ, Cha JY, Kim JG, Sung NJ (2008) Changes of physicochemical components and antioxidant activity of garlic during its processing. J Life Sci, 18, 1123-1131 
36. Woo KS, Hwang IG, Lee YR, Lee JS, Jeong HS (2009) Characteristics of sucrose thermal degradation with high temperature and high pressure treatment. Food Sci Biotechnol, 18, 717-723

37. Kim SD, Do JH, Oh HI (1981) Antioxidant activity of Panax ginseng browning products. Korea Ginseng and Tobacco Research Inst, 24, 161-166

38. Park HJ, Lee SH, Kim HY, Jang GY, Hwang IG, Woo KS, Kwon OS, Lee JS, Jeong HS (2012) Changes in chemical components and antioxidant activity of dried jujube with different aging temperatures and durations. J Korean Soc Food Sci Nutr, 41, 591-597

39. Park YH, Park SJ, Han GJ, Choe JS, Lee JY, Kang MS (2012) Quality characteristics of pre-processed garlic during storage according to storage temperature. J Korean Soc Food Sci Nutr, 41, 994-1001

40. Im GY, Jang SY, Jeong YJ (2010) Quality characteristics of Panax ginseng C. A. Meyer with steaming heat and wet grinding conditions. J Korean Soc Food Sci Nutr, 39, 1005-1010

41. Oh SI, Kim MJ (2014) Changes in quality characteristics of peeled chestnut 'tsukuba' according to storage temperature and peeling method. Korean J Plant Res, $27,72-79$
42. Lee HH, Hong SI, Kim DM (2012) Storage quality of ready-to-eat campbell table grapes as affected by active modified atmosphere packaging. Korean J Food Sci Technol, 44, 559-567

43. Hwang CR, Joung EM, Lee SH, Hwang IG, Kim YB, Jeong JH, Lee JS, Jeong HS (2013) Chemical components and enzyme activity of hydroponic-cultured ginseng roots and leaves under different heating temperatures. J Korean Soc Food Sci Nutr, 42, 911-916

44. Lee JW, Lee SK, Do JH, Shim KH (1998) Characteristic of the water soluble browning reaction of Korean red ginseng as affected by heating treatment. J Ginseng Res, 22, 193-199

45. Lee SH, Hwang IG, Lee YR, Joung EM, Jeong HS, Lee HB (2009) Physicochemical characteristics and antioxidant activity of heated radish (Raphanus sativus L.) extracts. J Korean Soc Food Sci Nutr, 38, 490-495

46. Cha JY, Kim SY, Jeong SJ, Cho YS (1999) Effects of hesperetin and naringenin on lipid concentration in orotic acid treated mice. J Life Sci, 9, 389-394

47. Seong JH, Han JP (1999) The qualitative differences of persimmon tannin and the natural removal of astringency. Korean J Food Preserv, 6, 66-70 